\title{
EFFECT OF INCLUDING EXTRUDED, ROLLED OR GROUND CORN IN DAIRY COW DIETS BASED ON DIRECT CUT GRASS SILAGE
}

\author{
Christian Alvarado G. ${ }^{1}$, René Anrique G. ${ }^{2 *}$, and Soledad Navarrete Q. ${ }^{2}$
}

\begin{abstract}
A study was conducted to determine the effect of corn (Zea mays L.) grain processing on intake, digestibility of nutrients and milk production and composition. The effect of extrusion on nutrient digestibility was evaluated in trial 1, using ground corn as a control. In trial 2, the effect of extrusion on intake was evaluated, comparing extruded corn of two densities (357 and $\left.308 \mathrm{~g} \mathrm{~L}^{-1}\right)$ with rolled corn $\left(507 \mathrm{~g} \mathrm{~L}^{-1}\right)$ as a control. In trial 3 , the effects of extrusion on milk production, digestibility and intake were evaluated; using steam rolled corn and ground corn as controls. No effects on dry matter and metabolizable energy intakes due to differences in the extruded corn grains were observed. Digestibility of dry matter, organic matter, crude protein, gross energy and neutral detergent fiber did not differ among treatments, although a greater digestibility of non-fibrous carbohydrates was observed. Higher milk production was obtained in treatments including extruded and steam rolled corn $\left(21.4\right.$ and $\left.21.6 \mathrm{~L} \mathrm{~d}^{-1}\right)$, compared to ground corn $\left(20.5 \mathrm{~L} \mathrm{~d}^{-1}\right)$ but differences disappeared when standardizing for fat content. Milk composition was not affected by treatments. Daily protein production was greater $(\mathrm{P}<0.01)$ in treatments including extruded and rolled corn. Blood parameters (ß-hydroxybutyrate, urea) and milk urea remained within normal reference values. It was concluded that using extruded corn had no adverse effects on digestibility or forage and total intake with a small advantage in milk protein yield comparing with ground corn, but without clear differences compared to steam rolled corn.
\end{abstract}

Key words: Extruded corn, intake, digestibility, milk production.

\section{INTRODUCTION}

Cereal grains are used as energy sources, with corn being one of the most important because of its high metabolizable energy (ME) content. Adult cattle, unlike sheep, have a limited capacity to masticate cereal grains, because of that it is considered essential to break the pericarp of the seed either through chemical or physical treatments. The exception is oats (Avena sativa L.), which cattle can utilize effectively when fed as whole grain (NRC, 2001b). There are diverse processing alternatives that have been well documented in the literature. In general, the literature confirms the need for processing grains such as corn (Zea mays L.) and sorghum (Sorghum bicolor L.), which are more resistant to rumen fermentation, with no generally significant differences detected among processing methods (Rowe et al., 1999;

Instituto de Investigaciones Agropecuarias INIA, Centro Regional de Investigación Carillanca, Casilla 58-D, Temuco, Chile.

${ }^{2}$ Universidad Austral de Chile, Facultad de Ciencias Agrarias, Casilla 567, Valdivia, Chile. *Corresponding author (ranrique@uach.cl).

Received: 04 April 2008.

Accepted: 20 September 2008.
Firkins et al., 2001). Heat processing; however, has been associated with increased efficiency of fermentative utilization by altering the protein matrix of the endosperm and the starch structure, thus allowing a better utilization by microbial enzymatic digestion.

Grain extrusion involves the use of moisture, high temperature and pressure to reach a high level of starch gelatinization. However, the effect of cereal grain extrusion has not been studied extensively with ruminants; unlike the effect of steam rolling and flaking, which have been frequently studied in relation to ruminal and post-ruminal utilization of nutrients (Rowe et al., 1999). The effects of extrusion, in terms of both nutritional and productive aspects, are contradictory and not very conclusive. For example, a decrease in intake (7\%) has been attributed to a lower density of extruded corn (Shabi et al., 1999) and a lower digestibility of the neutral detergent fiber (NDF) to a decrease in ruminal $\mathrm{pH}$ (Gaebe et al., 1998). Most studies have been conducted using the processed corn grain fed as a supplement of either corn silage, which has low fiber content, or alfalfa (Medicago sativa L.), with a significant buffering capacity that reduces the risk of acidosis. The objective of the present study was to evaluate the effects 
of extrusion of corn grain on intake, digestibility of nutrients and milk production and composition, using direct cut grass silage as the main component of the diet.

\section{MATERIALS AND METHODS}

\section{Feeds and processing}

Grains from the same batch were submitted to three processing techniques. One batch was extruded corn (EC) at $90{ }^{\circ} \mathrm{C}$ with 1.51 to $2.02 \mathrm{MPa}$ of pressure, and subsequently dried and cooled at room temperature until reaching 12 to $14 \%$ moisture. The extrusion process was modified to produce EC grains with two densities. A second batch was processed by steam rolling (SRC) at $100{ }^{\circ} \mathrm{C}$ for $55 \mathrm{~min}$ at atmospheric pressure, and a third batch was corn grains ground (GC) in a hammer mill with a $2.5 \mathrm{~mm}$ diameter sieve. The different grains were fed as a supplement to silage, which was a mixture of biannual ryegrass (Lolium multiflorum L.) with oats (Avena strigosa Schreb.). A commercial concentrate (Cosetán ${ }^{\circledR}$, Osorno, Chile) based on dried sugar beet (Beta vulgaris L.) pulp was applied at a ratio of $30 \mathrm{~kg} \mathrm{t}^{-1}$ of fresh forage as an absorbent additive. The feeds were used in three trials conducted at the Vista Alegre Experimental Station located $6 \mathrm{~km}$ north of the city of Valdivia $\left(39^{\circ} 47^{\prime} \mathrm{S} ; 73^{\circ} 12^{\prime}\right.$ W), between September and November of 2004. Table 1 summarizes the composition of the feeds.

\section{Trial 1}

In this trial the effect of EC intake on digestibility of the fibrous fraction of the ration was estimated, using 12 Friesian steers, categorized as light (L) and heavy $(\mathrm{H})$, with an average live weight (LW) of 155 and 185 $\mathrm{kg}$, respectively. The animals were kept in individual metabolism stalls designed for measuring intake and urine and fecal production. The treatments were defined by the level of inclusion of EC fed in increasing amounts in combination with $\mathrm{GC}$, so that the sum of the two represented $40 \%$ of the total ration. The difference $(60 \%)$ was composed of silage; all the rations were supplemented with a mineral mixture. The level of EC fluctuated between 10 and $40 \%$ and that of GC between 0 and $30 \%$ (Table 2). The level of feeding was approximately $80 \%$ of maximum intake, which was defined in a preliminary period of 14 days during which the experimental rations were fed ad libitum. For the following 6 days, fecal and urinary excretions were measured individually. Sampling of feed, feces and urine was done daily and a composite sample was made for each animal at the end of the period.

The feeds were analyzed for dry matter (DM), crude protein $(\mathrm{CP})$, total ash (TA), organic matter (OM) (AOAC, 2000), neutral detergent fiber (NDF) and acid detergent fiber (ADF) according to Van Soest (1991); metabolizable energy (ME) by regression EM $($ Mcal kg-1) $=0,279+$ 0,0325D (Garrido and Mann, 1981), where D is the in

Table 1. Composition of feeds used (DM basis).

\begin{tabular}{|c|c|c|c|c|c|c|c|c|c|}
\hline & \multicolumn{2}{|c|}{$\begin{array}{c}\text { Silage } \\
\text { (Trials 1, } 2 \text { and 3) } \\
\end{array}$} & \multicolumn{2}{|c|}{$\begin{array}{c}\text { Corn } \\
\text { (Trials } 1 \text { and 2) } \\
\end{array}$} & \multicolumn{3}{|c|}{ Corn (Trial 3) } & \multirow[b]{2}{*}{$\begin{array}{c}\text { Soybean } \\
\text { meal }\end{array}$} & \multirow[b]{2}{*}{$\begin{array}{l}\text { Alfalfa in } \\
\text { cubes }\end{array}$} \\
\hline & Oven $^{1}$ & Toluene $^{2}$ & Extruded & Ground & Extruded & $\begin{array}{l}\text { Steam } \\
\text { rolled }\end{array}$ & Ground & & \\
\hline DM, \% & 15.80 & 19.80 & 84.40 & 84.20 & 85.00 & 86.40 & 84.90 & 86.60 & 84.10 \\
\hline $\mathrm{TA}, \%$ & 7.09 & 5.67 & 1.34 & 1.42 & 1.36 & 0.78 & 1.64 & 6.82 & 9.41 \\
\hline $\mathrm{CP}, \%$ & 14.80 & 11.90 & 7.83 & 8.17 & 7.81 & 7.37 & 8.06 & 49.8 & 18.8 \\
\hline EE, \% & 5.14 & ND & - & - & 1.03 & 2.20 & 4.50 & 1.93 & 2.04 \\
\hline GE, Mcal kg-1 & 4.67 & ND & - & - & 4.41 & 4.36 & 4.58 & 4.84 & 4.54 \\
\hline ME, Mcal kg-1 & 2.56 & ND & 3.47 & 3.47 & 3.47 & 3.51 & 3.47 & 3.31 & 2.51 \\
\hline NDF, $\%$ & 58.55 & 46.78 & 8.43 & 11.98 & 8.29 & 8.03 & 11.70 & 8.60 & 37.87 \\
\hline $\mathrm{ADF}, \%$ & 38.74 & 30.95 & 2.20 & 2.69 & 2.55 & 2.63 & 3.97 & 5.91 & 29.91 \\
\hline NFC, $\%$ & 14.20 & 11.30 & 81.40 & 73.90 & 81.50 & 81.60 & 74.10 & 32.80 & 31.90 \\
\hline $\mathrm{Ca}, \%$ & 0.65 & 0.52 & - & - & 0.01 & 0.01 & 0.01 & 0.26 & 1.76 \\
\hline $\mathrm{P}, \%$ & 0.29 & 0.23 & - & - & 0.26 & 0.14 & 0.31 & 0.69 & 0.26 \\
\hline $\mathrm{Mg}, \%$ & 0.16 & 0.13 & - & - & 0.10 & 0.05 & 0.14 & 0.32 & 0.22 \\
\hline $\mathrm{pH}$ & 4.15 & 4.15 & & & & & & & \\
\hline $\mathrm{N}-\mathrm{NH}_{3}, \%$ of $\mathrm{N}$ & 11.59 & 11.59 & & & & & & & \\
\hline
\end{tabular}

DM: dry matter; TA: total ash; CP: crude protein; EE: ether extract; GE: gross energy; ME: metabolizable energy; NDF: neutral detergent fiber; ADF: acid detergent fiber; $\mathrm{NFC}$ : non-fibrous carbohydrates; $\mathrm{N}_{-} \mathrm{NH}_{3}$ : ammonia nitrogen. ND: not determined.

${ }^{1}$ Oven dried at $60^{\circ} \mathrm{C}$ and at $105^{\circ} \mathrm{C}$.

${ }^{2}$ Dry matter by toluene distillation. 
Table 2. Experimental rations used in trial 1.

\begin{tabular}{lccc}
\hline Treatment & $\begin{array}{c}\text { Extruded corn } \\
(\text { EC) }\end{array}$ & $\begin{array}{c}\text { Ground corn } \\
(\text { GC) }\end{array}$ & Silage \\
\cline { 2 - 4 } & & DM basis $\%$ & \\
\cline { 2 - 3 } EC10 & 10 & 30 & 60 \\
EC25 & 25 & 15 & 60 \\
EC40 & 40 & 0 & 60 \\
\hline
\end{tabular}

EC10: ration with $10 \% \mathrm{EC}$ and $30 \% \mathrm{GC}$; EC25: ration with $25 \% \mathrm{EC}$ and $15 \%$ GC; EC40: ration with only $40 \%$ EC.

vitro digestible $\mathrm{OM}$ as a percentage of DM (Goering and Van Soest, 1972). In the silage $\mathrm{pH}$ was determined with a pH meter (Orion SA520, Boston, Massachusetts, USA), calibrated with neutral ( $\mathrm{pH} 7$ ) and acidic solutions ( $\mathrm{pH} \mathrm{4):}$ $\mathrm{N}-\mathrm{NH}_{3}$ was determined in fresh silage samples, following distillation with an alkaline solution and subsequent titrated (AOAC, 2000) with DM determined under toluene (AOAC, 2000). In feces DM was determined in feces in lyophilized samples. $\mathrm{CP}, \mathrm{NDF}, \mathrm{ADF}$ and $\mathrm{OM}$ were also determined in lyophilized samples, according to the methodologies already described.

To evaluate the effect of the treatments on apparent digestibility, a completely randomized design was used with a factorial arrangement of treatments, according to the model: $Y_{i j}=\mu+M_{i}+P_{j}+M P_{i j}+E_{i j}$, where $Y_{\mathrm{ij}}$ is the dependent variable or apparent digestibility (DM, OM, $\mathrm{CP}, \mathrm{ADF}$ and $\mathrm{NDF}) ; \mu$ is the population mean; $\mathrm{M}_{\mathrm{i}}$ is a fixed effect of the $i^{\text {th }}$ treatment ( $\mathrm{i}=1,2$ or 3$) ; \mathrm{P}_{\mathrm{j}}$ is a fixed effect of the $j^{\text {th }}$ animal weight category $(\mathrm{j}=1$ or 2$)$; $\mathrm{MP}_{\mathrm{ij}}$ is the interaction between treatment and animal weight category; and $\mathrm{E}_{\mathrm{ij}}$ is the experimental error.

\section{Trial 2}

This trial was designed to study the effect of the density of the EC on intake. Twelve Friesian steers were used, with an average LW of $172 \mathrm{~kg}$, randomly assigned to three groups. The steers were kept in individual metabolism stalls. The same silage used in Trial 1 was offered ad libitum, plus a supplement of soybean (Glycine $\max ($ L.) Merr.) meal fed in a fixed quantity equivalent to $0.12 \%$ of body weight (BW, between 0.17 and 0.25 $\mathrm{kg})$. The treatments were determined by the type of corn offered: EC of average density (MDEC) $\left(357 \mathrm{~g} \mathrm{~L}^{-1}\right)$, EC of low density (LDEC) $\left(308 \mathrm{~g} \mathrm{~L}^{-1}\right)$ or $\mathrm{GC}\left(507 \mathrm{~g} \mathrm{~L}^{-1}\right)$; in all treatments the grains were offered at a rate of $0.8 \%$ of BW with the average supply of corn being $1.3 \mathrm{~kg} \mathrm{~d}^{-1}$ animal-1 in two feedings. The trial lasted 20 days, with the first 12 days used for diet adaptation. All measurements were concentrated in the last 8 days, during which individual records were kept of offered and rejected feed; effective DM intake was determined by difference. All feeds were sampled for analysis in a way similar to trial 1 .

An ANOVA on daily intake data was carried out, expressed as g DM per unit of metabolic body weight $\left(\mathrm{BW}^{0.75}\right)$, following a completely randomized design of three treatments with four replicates, according to the model: $Y_{i j}=\mu+M_{i}+E_{i j}$, where, $\mathrm{Y}_{\mathrm{ij}}$ is the dependent variable or DM intake; $\mu$ is the population mean; $\mathrm{M}_{\mathrm{i}}$ is the fixed effect of the $i^{\text {th }}$ treatment ( $\mathrm{i}=1,2$ or 3$)$; and $\mathrm{E}_{\mathrm{ij}}$ is the experimental error.

\section{Trial 3}

In this trial 12 Friesian milking cows with more than two lactations, homogenous in production, LW and calving date, were assigned to three groups of four animals each. The animals were individually stalled with free access to water and milked twice daily. The basal diet was the same silage utilized in Trials 1 and 2, supplemented with soybean meal, alfalfa cubes and a mineral mixture. In addition, the three groups were supplemented with corn grain processed either as extruded (EC), steam rolled (SRC) or ground (GC), determining three treatments. The diets were administered three times daily while the cows were in their stalls in the amounts indicated in Table 3.

The trial was divided into three periods, each cow receiving sequentially the three treatments, according to a crossover design of four $3 \times 3$ Latin-squares (three treatments times three periods). Each period lasted 21 days, the first 14 days were a stabilization phase, with measurements and sampling concentrated in the last 7 days of each period. Individual intake was measured daily by the difference between the feed offered and rejected. Digestibility was determined individually by relating intake and fecal production, estimated with chromium oxide $\left(\mathrm{Cr}_{2} \mathrm{O}_{3}\right)$ as external marker. Boluses made from wheat flour and a fixed quantity of $\mathrm{Cr}_{2} \mathrm{O}_{3}$ were administered

Table 3. Description of diets used in Trial 3 (kg, as fed basis).

\section{Corn}

\begin{tabular}{|c|c|c|c|c|c|c|}
\hline Treatment & Extruded (EC) & Steam rolled (SRC) & Ground (GC) & Soybean meal & Alfalfa & Silage \\
\hline & & & $-\mathrm{kg}$ & 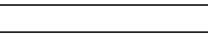 & - & \\
\hline $\mathrm{EC}$ & 3.85 & - & - & 1.3 & 1.3 & ad libitum \\
\hline $\mathrm{SRC}$ & - & 3.85 & - & 1.3 & 1.3 & ad libitum \\
\hline $\mathrm{GC}$ & - & - & 3.85 & 1.3 & 1.3 & ad libitum \\
\hline
\end{tabular}


from days 10 to 21 of each period at a ratio of $18 \mathrm{~g}$ daily in two portions after each feeding. Feces were sampled in the last 5 days of each period, collecting $200 \mathrm{~g}$ per animal daily and producing a composite sample per animal and period. Milk production was measured during the last 7 days with milk samples taken for 3 days $\left(3^{\text {rd }}, 4^{\text {th }}\right.$ and $\left.5^{\text {th }}\right)$. On the last day of each period an individual blood sample was taken after the morning feeding.

In addition, the following determinations were made in feeds and feces: ether extract (EE), gross energy (GE), Ca, $\mathrm{P}, \mathrm{Mg}$, and $\mathrm{Cr}_{2} \mathrm{O}_{3}$. Ether extract was analyzed according to AOAC (2000). EB was determined in an adiabatic calorimeter (Parr 1242, Parr Instrument Company, Moline, Illinois, USA). $\mathrm{Ca}$ and $\mathrm{Mg}$ were determined by atomic absorption spectrophotometry after digestion with nitric and perchloric acids (AOAC, 2000). P was determined by the vanado-molybdate method (AOAC, 2000). Non-fibrous carbohydrates (NFC) were estimated by difference with the formula:

$$
\mathrm{NFC}(\%)=100 \%-[\mathrm{PC}(\%)+\mathrm{FDN}(\%)+\mathrm{EE}(\%)+\mathrm{CT}(\%)]
$$

Protein, fat, lactose and urea were analyzed in milk, using an automated infrared spectrophotometer(Milkoscan, Foss Electric, Hillerød, Denmark). Urea in serum was measured by colorimetry with glutamate dehydrogenase, an enzymatic method for kinetic determination of urea (Tietz, 2001) using standard Human ${ }^{\circledR} \mathrm{N}^{\circ} 10521$ (Wiesbaden, Germany). Plasma $\beta$-hydroxybutyrate (ß-HBA) concentration (as an indicator of energy balance) was determined by an enzymatic technique, oxidizing the B-HBA with $\mathrm{NAD}+$ (nicotinamide adenine dinucleotide), through 3-hydroxybutyrate deshydrogenase enzyme to acetoacetate. The quantity of reduced NAD + was measured in a spectrophotometer (Hitachi 4020, Roche Diagnostics, Mannheim, Germany) at $340 \mathrm{~nm}$.

Fecal production was estimated with the following equation (Miron et al., 2002):

$$
\text { Fecal production }\left(\mathrm{kg} \mathrm{d}^{-1}\right)=\frac{\begin{array}{c}
\text { Daily intake of } \\
\text { chromic oxide }(\mathrm{g})
\end{array}}{\begin{array}{c}
\text { Chromic oxide concen- } \\
\text { tration in feces }(\%) * 10
\end{array}}
$$

Digestibility of any given fraction was measured using the following equation:

$\begin{aligned} & \text { Digestibility of } \\ & \text { fraction X (\%) }\end{aligned}=\frac{\text { consumed } \mathrm{kg} \mathrm{d}^{-1}-{\text { excreted } \mathrm{kg} \mathrm{d}^{-1}}^{-1}}{\text { consumed } \mathrm{kg} \mathrm{d}^{-1}} * 100$

A general lineal model was used to analyze these data, which included the fixed effects of treatment, period and Latin square, separating media using the Tukey test $(\mathrm{P}>$ 0.05).

$$
Y_{i j k m}=\mu+T_{j}+P_{k}+C_{i}+V_{m}+E_{i j k m}
$$

where, $Y_{\mathrm{ijkm}}$ is the dependent variable; $\mu$ is the population mean; $T_{j}$ is the fixed effect of the $j^{\text {th }}$ treatment $(j=1,2$ or 3 ); $\mathrm{P}_{\mathrm{k}}$ is the fixed effect of the $k^{\text {th }}$ period $(\mathrm{k}=1,2$ or 3$)$; $\mathrm{C}_{\mathrm{i}}$ is the fixed effect of the $i^{\text {th }}$ square $(\mathrm{i}=1,2,3$ or 4$)$; $\mathrm{V}_{\mathrm{m}}$ is the fixed effect of $m^{\text {th }}$ cow $(\mathrm{m}=1,2,3, \ldots, 10,11$ or 12$)$; and $\mathrm{E}_{\mathrm{ijkm}}$ is the residual error.

\section{RESULTS}

\section{Trial 1}

Results of the apparent digestibility (DM, MO, GP, $\mathrm{NDF}$ and $\mathrm{ADF}$ ) of the three experimental rations are presented in Table 4 by weight category of the animals. No significant $(\mathrm{P}>0.05)$ effects of level of intake of extruded corn (EC), animal weight or the interaction between EC intake and animal weight on apparent digestibility of the ration $\mathrm{DM}, \mathrm{OM}, \mathrm{CP}, \mathrm{FDN}$ or $\mathrm{ADF}$ were detected

\section{Trial 2}

No significant differences in silage or total ration intake were observed between fed rations supplemented with rolled or extruded corn grain. Ration intake (expressed as g per kg of metabolic weight) did not differ when comparing EC vs. GC. Intake was also similar when comparing the rations supplemented with low or medium density extruded corn (MDEC vs. LDEC) ( $\mathrm{P}>0.05$ ). Silage intake fluctuated between 83.65 and $90.11 \mathrm{~g} \mathrm{DM}$ $\mathrm{d}^{-1} \mathrm{~kg}^{-1} \mathrm{BW}^{0.75}$ and total DM intake ranged between 112.45 and $117.41 \mathrm{~g} \mathrm{~d}^{-1} \mathrm{~kg}^{-1} \mathrm{BW}^{0.75}$ (Table 5).

\section{Trial 3}

Silage intake and total ration intake were similar among treatments $(\mathrm{P}>0.05)$. Silage DM intake was 11.2, 11.5 and a.11.4 kg for the EC, SRC and GC treatments, respectively. Total DM intake was $16.7 ; 17.0$ and 16.9 $\mathrm{kg} \mathrm{d}^{-1}$ for the EC, SRC and GC treatments, respectively (Table 6).

Apparent digestibility of DM, OM, CP, NDF, ADF, and GE of the diets did not differ $(\mathrm{P}>0.05)$, however, digestibility of NFC approached significance $(\mathrm{P}<0.063)$. A higher digestibility of NFC was observed with the ration supplemented with EC (82.63\%); an intermediate level was obtained with SRC (81.18\%), and the lowest digestibility was observed on the ration supplemented with GC $(77.42 \%)$.

Differences were found in non-standardized milk production $(\mathrm{P}<0.05)$. The highest production was reached with the rations supplemented with EC and SRC, without differences between them, and the lowest with the GC treatments $\left(21.4,21.6\right.$ and $20.5 \mathrm{~L} \mathrm{~d}^{-1}$, for EC, SRC and $\mathrm{GC}$, respectively). These differences disappeared when 
Table 4. Effect of the level of extruded corn inclusion and body weight on apparent digestibility of the diet (Trial 1).

\begin{tabular}{|c|c|c|c|c|c|c|c|}
\hline & \multicolumn{3}{|c|}{ Rations } & \multicolumn{2}{|c|}{ Animals } & \multicolumn{2}{|c|}{ Significance } \\
\hline & EC10 & EC25 & EC40 & Heavy & Light & Rations & Animals \\
\hline & & & $\%$ & &  & & \\
\hline DM & $73.7 \pm 1.64$ & $73.6 \pm 2.18$ & $75.5 \pm 1.85$ & $74.9 \pm 1.07$ & $73.7 \pm 2.51$ & ns & ns \\
\hline OM & $75.3 \pm 1.41$ & $75.1 \pm 1.99$ & $77.1 \pm 1.82$ & $76.4 \pm 1.07$ & $75.3 \pm 2.39$ & ns & ns \\
\hline $\mathrm{CP}$ & $56.7 \pm 5.11$ & $55.1 \pm 5.03$ & $58.6 \pm 4.42$ & $57.6 \pm 2.96$ & $56.1 \pm 5.71$ & ns & $\mathrm{ns}$ \\
\hline NDF & $71.0 \pm 5.39$ & $65.3 \pm 3.35$ & $66.1 \pm 4.06$ & $68.4 \pm 5.57$ & $66.5 \pm 3.13$ & ns & ns \\
\hline $\mathrm{ADF}$ & $68.8 \pm 4.29$ & $64.5 \pm 3.24$ & $66.4 \pm 4.42$ & $67.6 \pm 4.95$ & $65.5 \pm 3.04$ & ns & ns \\
\hline
\end{tabular}

EC10: ration with 10\% extruded corn (EC) and 30\% ground corn (GC); Me25: ration with 25\% EC and 15\% GC: EC40: ration with only 40\% EC; DM: dry matter; OM: organic matter; CP: crude protein; NDF: neutral detergent fiber; ADF: acid detergent fiber; ns: not significant $(\mathrm{P}>0.05)$.

Table 5. Effect of density of extruded corn grain on intake (Trial 2).

\begin{tabular}{|c|c|c|c|c|}
\hline & \multicolumn{3}{|c|}{ Intake } & \multirow[b]{2}{*}{ Significance } \\
\hline & SRC & ECMD & ECLD & \\
\hline & 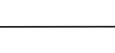 & $\mathrm{g} \mathrm{DM} \mathrm{d}^{-1} \mathrm{~kg}^{-1} \mathrm{MW}$ & 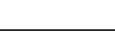 & \\
\hline Silage & 83.65 & 86.78 & 90.11 & ns \\
\hline Total & 112.45 & 113.93 & 117.41 & ns \\
\hline
\end{tabular}

MW: metabolic weight; SRC: steam rolled corn (507 g L $\left.{ }^{-1}\right)$; ECMD: extruded corn medium density $\left(357 \mathrm{~g} \mathrm{~L}^{-1}\right)$; ECLD: extruded corn low density (308 $\left.\mathrm{g} \mathrm{L}^{-1}\right)$; ns: not significant $(\mathrm{P}>0.05)$.

fat corrected milk data were analyzed $(20.8,20.8$ and 20.0 $\mathrm{L} \mathrm{d}^{-1}$ for the rations supplemented with $\mathrm{EC}, \mathrm{SRC}$ and $\mathrm{GC}$, respectively).

Fat, protein and lactose contents were similar among treatments, with a tendency $(\mathrm{P}=0.075)$ to a higher protein concentration when the corn grain was supplemented as EC and GC. Protein yields $(0.65,0.64$ and $0.60 \mathrm{~kg}$ for the EC, SRC and GC diets, respectively) were similar between treatments $\mathrm{EC}$ and SRC and both were higher than the ration supplemented with GC $(\mathrm{P}<0.01)$. A similar situation was observed with lactose yield $(\mathrm{P}<$ $0.05)$, with the SRC treatment having the highest value $\left(1.08 \mathrm{~kg} \mathrm{~d}^{-1}\right)$, followed by EC (1.07 $\left.\mathrm{kg} \mathrm{d}^{-1}\right)$ and GC (1.02 $\left.\mathrm{kg} \mathrm{d}^{-1}\right)$. Fat yields did not differ among treatments $(\mathrm{P}>$ 0.05); however, a significant response was observed in the amount of milk energy produced, which was higher with EC and SRC diets (15.99 and 15.94 $\mathrm{Mcal} \mathrm{d}^{-1}$, respectively) in comparison with the GC ration, with an estimated energy production of 15.22 Mcal (Table 6).

There were also no differences in ME intake (MEI) or in Mcal of MEI per liter of milk. Significant differences were observed $(\mathrm{P}<0.05)$ in net energy of lactation $\left(\mathrm{NE}_{\mathrm{L}}\right)$ per unit of $\mathrm{ME}$ consumed, the highest value being in the EC treatment (0.341 Mcal per Mcal of ME consumed), which did not differ from the SRC treatment $(0.335 \mathrm{Mcal}$ per Mcal of ME consumed) but were higher than the GC treatment (0.324 Mcal per Mcal of ME consumed).

No differences were found among treatments $(\mathrm{P}>$ $0.05)$ for $ß-\mathrm{HBA}$ and blood urea, all values are considered normal (Table 7). Levels of $\beta-H B A$ varied between 0.388 (EC diet) and $0.458 \mathrm{mmol} \mathrm{L}^{-1}$ (GC diet), with normal reference values between 0 and $1.0 \mathrm{mmol} \mathrm{L}^{-1}$. Blood urea varied between 3.580 and $4.104 \mathrm{mmol} \mathrm{L}^{-1}$ for $\mathrm{GC}$ and $\mathrm{EC}$ treatments, respectively, values between 2.5 and $7.0 \mathrm{mmol}$ $\mathrm{L}^{-1}$ are considered as normal (Wittwer, 2000). However differences were observed $(\mathrm{P}<0.05)$ in milk urea content, with the lower level found with the ration supplemented with GC $\left(5.868 \mathrm{mmol} \mathrm{L}^{-1}\right)$ and the higher for the ration supplemented with EC (6.248 $\left.\mathrm{mmol} \mathrm{L}^{-1}\right)$. Wittwer (2000) considers as normal reference values between 2.5 and 7.0 $\mathrm{mmol} \mathrm{L}{ }^{-1}$.

\section{DISCUSSION}

\section{Composition of the feed}

The untreated corn grain used had a composition according to expected standards (NRC, 2001a; Anrique et al., 2008), with a mean ME value of $3.3 \mathrm{Mcal} \mathrm{kg}^{-1} \mathrm{DM}$, 4.0\% EE, 8.2\% CP and 9.5\% NDF. Grinding produced a $11.7 \%$ reduction of NDF content grinding, and of $8.29 \%$ and $8.03 \%$ from extrusion and steam rolling, respectively. A similar situation was observed with EE content, which decreased by $4.5,1.03$ and $2.20 \%$ in GC, EC and SRC, respectively. The differences in fiber content among $\mathrm{GC}$, SRC and EC can be attributed to partial solubilization of the fiber due to the processing temperature. Prestløkken and Harstad (2001) compared pelleted (75 to $80{ }^{\circ} \mathrm{C}$ ) to expanded barley and subsequently pelleted barley (125 to 
Table 6. Effect of type of corn on intake, digestibility, milk production and efficiency (Trial 3).

\begin{tabular}{|c|c|c|c|}
\hline & Extruded corn & Steam rolled corn & Ground corn \\
\hline \multicolumn{4}{|l|}{ Intake of DM } \\
\hline Silage $^{1}, \mathrm{~kg} \mathrm{~d}^{-1}$ & $11.2 \pm 0.72 \mathrm{a}$ & $11.5 \pm 1.46 \mathrm{a}$ & $11.4 \pm 0.72 \mathrm{a}$ \\
\hline Extruded corn, $\mathrm{kg} \mathrm{d}^{-1}$ & 3.3 & - & - \\
\hline Rolled corn, $\mathrm{kg} \mathrm{d}^{-1}$ & - & 3.3 & - \\
\hline Ground corn, $\mathrm{kg} \mathrm{d}^{-1}$ & - & - & 3.3 \\
\hline Soybean meal, $\mathrm{kg} \mathrm{d}^{-1}$ & 1.1 & 1.1 & 1.1 \\
\hline Alfalfa pellets, $\mathrm{kg} \mathrm{d}^{-1}$ & 1.1 & 1.1 & 1.1 \\
\hline Total $\mathrm{DM}^{1}, \mathrm{~kg} \mathrm{~d}^{-1}$ & $16.7 \pm 1.03 \mathrm{a}$ & $17.0 \pm 1.91 \mathrm{a}$ & $16.9 \pm 1.36 \mathrm{a}$ \\
\hline \multicolumn{4}{|l|}{ Digestibility } \\
\hline $\mathrm{DM}, \%$ & $76.70 \pm 2.12$ & $74.80 \pm 5.45$ & $74.50 \pm 6.07$ \\
\hline $\mathrm{OM}, \%$ & $78.97 \pm 2.00$ & $77.52 \pm 4.49$ & $76.84 \pm 5.51$ \\
\hline $\mathrm{CP}, \%$ & $73.51 \pm 3.23$ & $71.95 \pm 5.00$ & $72.14 \pm 7.63$ \\
\hline $\mathrm{GE}, \%$ & $73.25 \pm 2.65$ & $71.22 \pm 5.74$ & $70.79 \pm 7.24$ \\
\hline NDF, $\%$ & $70.21 \pm 2.70$ & $67.97 \pm 6.56$ & $69.29 \pm 7.47$ \\
\hline $\mathrm{NFC}^{2}, \%$ & $82.63 \pm 2.14 \mathrm{a}$ & $81.18 \pm 5.22 \mathrm{ab}$ & $77.42 \pm 4.72 b$ \\
\hline \multicolumn{4}{|l|}{ Milk production } \\
\hline Non-standardized milk ${ }^{1}, \mathrm{~L} \mathrm{~d}^{-1}$ & $21.4 \pm 3.43 \mathrm{ab}$ & $21.6 \pm 3.87 \mathrm{a}$ & $20.5 \pm 3.09 b$ \\
\hline Standardized milk at $4 \% \mathrm{MG}, \mathrm{L} \mathrm{d}^{-1}$ & $20.8 \pm 3.46$ & $20.8 \pm 3.98$ & $20.0 \pm 2.75$ \\
\hline $\mathrm{Fat}^{4}, \%$ & $3.81 \pm 0.39$ & $3.76 \pm 0.50$ & $3.85 \pm 0.38$ \\
\hline Protein $^{3}, \%$ & $3.02 \pm 0.23 \mathrm{a}$ & $2.99 \pm 0.21 \mathrm{a}$ & $2.95 \pm 0.22 b$ \\
\hline Lactose, $\%$ & $5.02 \pm 0.21$ & $5.02 \pm 0.22$ & $4.99 \pm 0.30$ \\
\hline $\mathrm{Fat}^{4}, \mathrm{~kg} \mathrm{~d}^{-1}$ & $0.82 \pm 0.15$ & $0.81 \pm 0.17$ & $0.79 \pm 0.11$ \\
\hline Protein $^{3}, \mathrm{~kg} \mathrm{~d}^{-1}$ & $0.65 \pm 0.11 \mathrm{a}$ & $0.64 \pm 0.11 \mathrm{a}$ & $0.60 \pm 0.10 \mathrm{~b}$ \\
\hline Lactose $^{1}, \mathrm{~kg} \mathrm{~d}^{-1}$ & $1.07 \pm 0.17 \mathrm{ab}$ & $1.08 \pm 0.20 \mathrm{a}$ & $1.02 \pm 0.15 b$ \\
\hline $\mathrm{NE}_{\mathrm{L}}^{1}, \mathrm{Mcal} \mathrm{d}^{-1}$ & $15.97 \pm 2.67 \mathrm{a}$ & $15.94 \pm 2.99 \mathrm{a}$ & $15.22 \pm 2.07 \mathrm{~b}$ \\
\hline \multicolumn{4}{|l|}{ Efficiency } \\
\hline MEI, Mcal d ${ }^{-1}$ & $46.6 \pm 3.09$ & $47.6 \pm 5.31$ & $46.9 \pm 4.01$ \\
\hline MEI L $\mathrm{L}^{-1}$ of milk, Mcal d $\mathrm{d}^{-1}$ & $2.285 \pm 0.31$ & $2.339 \pm 0.35$ & $2.371 \pm 0.21$ \\
\hline $\mathrm{NE}_{\mathrm{L}}$ produced/EM consumed ${ }^{2}$ & $0.341 \pm 0.044 \mathrm{a}$ & $0.335 \pm 0.051 \mathrm{ab}$ & $0.324 \pm 0.030 \mathrm{~b}$ \\
\hline
\end{tabular}

DM: dry matter; OM: organic matter; CP: crude protein; GE: gross energy; NDF: neutral detergent fiber; NFC: non-fibrous carbohydrates; MEI: metabolizable energy intake. $\mathrm{EN}_{\mathrm{L}}$ : net energy of lactation. ME: metabolizable energy.

${ }^{1}$ Values with different letters within a line differ significantly $(\mathrm{P}<0.05)$.

${ }^{2}$ Values with different letters within a line differ significantly $(\mathrm{P}<0.063)$.

${ }^{3}$ Values with different letters within a line differ significantly $(\mathrm{P}<0.075)$.

${ }^{4}$ Values with different letters within a line differ significantly $(\mathrm{P}<0.01)$.

$130{ }^{\circ} \mathrm{C}$ ) and observed a reduction of NDF content from $15.2 \%$ to $16.5 \%$. Crocker et al. (1998) found that NDF content decreased from $15.3 \%$ in whole corn to $13.4 \%$ in extruded corn, obtaining an intermediate value $(14.3 \%)$ with dry rolled corn. In another study (Delahoy et al., 2003), NDF content decreased by $11.3 \%$ in ground corn and $8.1 \%$ in steam flaked corn.

The silage had slightly more protein and ME (14.8\%, $\left.2.56 \mathrm{Mcal} \mathrm{kg}^{-1} \mathrm{EM}\right)$ than the average of good quality grass silages in southern Chile (14.6\% PC and $2.46 \mathrm{Mcal} \mathrm{kg}^{-1}$ EM) according to Berndt (2002). PC and ME content could have been influenced by the absorbent additive (17.6\% PC and $3.04 \mathrm{Mcal} \mathrm{kg}^{-1} \mathrm{ME}$ ), which represented approximately $14 \%$ of the silage DM ensiled. While the $\mathrm{pH}$ of the silage was acceptable (4.15), the $\mathrm{N}-\mathrm{NH}_{3}$ content $(11.6 \%$ of total $\mathrm{N})$ shows that the fermentative quality was lower than desired given the negative relationship between $\mathrm{N}-\mathrm{NH}_{3}$ levels with intake (Steen et al., 1998). This high ammonia $\mathrm{N}$ content is explained mainly by the activity of forage proteases and peptidases at the beginning of ensiling and to microbial proteases during fermentation favored by the high water content, typical of direct cut 
Table 7. Concentration of $\beta$-hydroxybutyrate, blood and milk urea (average \pm standard deviation) and reference values (Wittwer, 2000).

\begin{tabular}{llllc}
\hline & \multicolumn{1}{c}{ EC } & \multicolumn{1}{c}{ SRC } & \multicolumn{1}{c}{ GC } & Reference \\
\hline$\beta$-Hydroxybutyrate, mmol L & $0.388 \pm 0.111$ & $0.396 \pm 0.174$ & $0.458 \pm 0.235$ & $0-1.0$ \\
Blood urea, mmol L & $4.104 \pm 0.95$ & $3.705 \pm 0.58$ & $3.580 \pm 0.83$ & $2.5-7.0$ \\
Milk urea $^{1}, \mathrm{mmol} \mathrm{L}^{-1}$ & $6.248 \pm 0.57 \mathrm{a}$ & $6.052 \pm 0.53 \mathrm{ab}$ & $5.868 \pm 0.87 \mathrm{~b}$ & $2.5-7.0$ \\
\hline
\end{tabular}

Values with different letters within a line differ significantly $(\mathrm{P}<0.05)$.

EC: extruded corn; SRC: steam rolled corn; GC: ground corn.

silages. The NDF content of the silage (58.55\%) is within the NDF range (55 and 60\%) found for silages with more than $13 \%$ PC according to Berndt (2002). It is important to emphasize that the NDF content of grass silages is much higher compared to corn silage ( $45 \% \mathrm{NDF}$; NRC, 2001), which has been the main silage used in studies in which the effect of extruded corn supplementation on milk production has been evaluated. Rastani and Andrew (1999) used a ration with $46 \%$ of silage, of which $81 \%$ was corn silage, and Shabi et al. (1999) included 36.5\% of corn silage in the diet. In the present study, grass silage represented $67 \%$ of ingested DM (Table 6).

\section{Intake}

The similar results found among treatments in Trials 2 and 3, show that ad libitum silage intake, as well as total intake, were independent of the type of corn used as an energy supplement. Consequently, the lower intake (7\%) with EC as a supplement found by Shabi et al. (1999) possibly are not explained by the lower EC density. In that study, a ration with $40 \%$ GC was compared to a $20 \% \mathrm{GC}$ and $20 \%$ EC diet, with corn silage as the only forage. In our study, corn grain intake represented $24 \%$ of the diet in Trial 1 and 20\% in Trial 2, lower levels than those reported previously. In Trial 2, the densities of EC were 308 and $357 \mathrm{~g} \mathrm{~L}^{-1}$ (LDEC and MDEC, respectively), and in Trial 3 the EC grain had a density of $357 \mathrm{~g} \mathrm{~L}^{-1}$; rolled corn fed in trials 2 and 3 had a density of $507 \mathrm{~g} \mathrm{~L}^{-1}$, showing that the method of corn processing, should not significantly influence intake at the levels used.

The results obtained agree with those of other studies in which the effect of grain density on intake has been evaluated. Plascencia and Zinn (1996) compared dry rolled corn $\left(520 \mathrm{~g} \mathrm{~L}^{-1}\right)$ and steam flaked corn at three densities $\left(390,320\right.$ and $\left.260 \mathrm{~g} \mathrm{~L}^{-1}\right)$. No differences in intake were found due to density of EC. On the contrary, comparing with dry rolled corn (the latter with higher density) greater intake was observed with steam flaked corn $(\mathrm{P}<0.05)$. Also, Joy et al. (1997) found no effects on DM intake when comparing dry rolled corn $\left(540 \mathrm{~g} \mathrm{~L}^{-1}\right)$ and steam flaked corn of two densities (390 and 310 $\left.\mathrm{g} \mathrm{L}^{-1}\right)$. In another study, Yu et al. (1998), including 40\% corn with different processing's in a diet with alfalfa hay as the main forage, did not find differences in intake when comparing coarsely GC $\left(618 \mathrm{~g} \mathrm{~L}^{-1}\right)$, finely ground corn (580 $\left.\mathrm{g} \mathrm{L}^{-1}\right)$, low density steam flaked corn $\left(309 \mathrm{~g} \mathrm{~L}^{-1}\right)$, medium density steam flaked corn $\left(361 \mathrm{~g} \mathrm{~L}^{-1}\right)$ and high density SRC (490 $\left.\mathrm{g} \mathrm{L}^{-1}\right)$. On the contrary, lower intake was observed when using finely ground corn, showing that in these studies density probably was not the main factor determining intake. On the other hand, Gaebe et al. (1998), in two weight gain studies with steers, compared EC and dry rolled corn ( $78.6 \%$ of the diet), and detected a 31 and $36 \%$ lower intake with EC, findings that the authors attributed to a probable effect of ruminal $\mathrm{pH}$, which decreased rapidly and remained low for a period of around $10 \mathrm{~h}$, producing a subclinical acidosis.

In the aforementioned works, when using $40 \%$ of corn grain in the diet (Rastani and Andrew, 1999; Shabi et al., 1999), the depressing effect on intake was low (7\%). In our study, the inclusion of corn in the diet was much lower $(20 \%)$ being less likely to produce a negative effect on intake associated with a reduced ruminal $\mathrm{pH}$. Nevertheless, Shabi et al. (1999) with $40 \%$ corn found no effect on ruminal $\mathrm{pH}$, therefore, the authors attributed their results to the lower density of extruded corn. In this sense, Tothi et al. (2002) indicate that the effects of thermal processing of corn grain on DM intake have been inconsistent. Chen et al. (1994) reported higher intake with steam flaked sorghum compared to dry rolled sorghum. Oliveira et al. (1993) observed a decrease in intake, while Simas et al. (1997) found no effect, suggesting that factors specific to the animals (stage of lactation, body condition) or environmental factors should also affect DM intake.

\section{Digestibility}

The only detectable effect of corn processing was a tendency to a higher digestibility of NFC $(\mathrm{P}<0.06)$ found in Trial 3. The absence of effects on apparent digestibility agree with what was reported by Shabi et al. (1999), who found no significant differences in digestibility in dairy cows, when comparing EC to GC included at $40 \%$ of the diet. Also, Gaebe et al. (1998) did not find any difference in digestibility between extruded and dry rolled corn when feeding steers. Other corn processing methods also show no significant effects on digestibility. In studies that 
compare GC to SRC as a supplement for grazing cows (Reis and Combs, 2000) or grass silage (Khalili et al., 2002). Digestibility differences were not observed either when comparing dry rolled corn to steam flaked corn (Joy et al., 1997; Crocker et al., 1998) or pelleted and expanded corn (Prestløkken and Harstad, 2001).

However, corn processing can reduce the digestibility of NDF and increase ruminal degradation of starch (or of NFC, NRC, 2001b). For example, Gaebe et al. (1998), when replacing dry rolled corn with EC, found no differences in DM digestibility, but a decrease in NDF digestibility (from 58.2 to $44.9 \%$ ) and an increase in starch digestibility (from 85.5 to $96.4 \%$ ). In the latter work, corn represented almost $80 \%$ of the diet; under these circumstances, a lowering effect on ruminal $\mathrm{pH}$ and therefore on fiber digestibility, should be expected. Yu et al. (1998) compared the effects of GC, EC and SRC on milk production and observed a reduction in ration NDF digestibility, which was negatively correlated to starch digestibility, an effect that was attributed to a subclinical acidosis. A lower digestibility of NDF is normally associated with a reduction of ruminal cellulolitic activity because of the lower $\mathrm{pH}$. As well, starch per se has been described as a depressant of fiber digestibility, independent of the reduction in ruminal $\mathrm{pH}$ (Hoover, 1986). In the present study, it is probable that the inclusion of only $20 \%$ of corn in the diet did not affect ruminal $\mathrm{pH}$, which could explain the lack of effect on NDF digestibility, although NDF levels were much higher than in the cited works, in which corn silage was used.

\section{Productive responses}

The higher milk production of the treatment with SRC (Table 6) can be attributed to greater available energy at the ruminal level, given that corn is more degradable (Shabi et al., 1999), a difference which is offset when data are analyzed as fat corrected milk. Our results do not agree with those of Shabi et al. (1999), who observed a significant reduction in milk production (from $26.4 \mathrm{~L} \mathrm{~d}^{-1}$ with $\mathrm{GC}$ to $25.6 \mathrm{~L} \mathrm{~d}^{-1}$ ) when using EC $(\mathrm{P} \leq$ 0.011). Rastani and Andrew (1999) measured a decrease in $4 \%$ fat corrected milk production from 41.3 to $37.7 \mathrm{~L} \mathrm{~d}^{-1}$ when replacing a pelleted ground corn with EC. In our trial, fat and lactose contents did not differ among treatments; however, milk protein content and daily protein and lactose yields (lactose yield was not different between EC and GC) were higher for treatments using EC and SRC (Table 6), explained mainly by a higher milk yield. In contrast, Shabi et al. (1999) found lower yields of protein, fat and lactose when cows were fed EC diets, explained by lower intakes compared to GC diets.

Extrusion and steam rolling, in addition to breaking the external cover of corn grain, produce an important level of gelatinization of starch, which favors its ruminal degradation (Rowe et al., 1999). Higher degradability results in higher production of volatile fatty acids and more efficient use of soluble protein and NPN, increasing microbial growth, with the consequent improvement of production. Depeters and Cant (1992), having analyzed 13 studies, found a positive correlation between energy intake and milk protein concentration, increasing the level of protein by 0.015 for each additional megacalorie of net energy intake. This relationship has also been proposed by Phillips (2001). These observations are consistent with the higher concentration of milk protein $(\mathrm{P}<0.075)$ found in the treatments that included EC and SRC, possibly reflecting a higher availability of energy in the rumen. However, a high rate of starch fermentation, stimulated by exceeding levels of inclusion of fermentable starch, can produce a reduction of ruminal $\mathrm{pH}$, affecting rumen functioning and digestibility of fiber, with negative consequences in the level of milk fat and production (Hoover and Miller-Webster, 1998).

While there were significant differences in milk urea contents among treatments (Table 7), the levels were within the normal reference values (between 2.5 and $7.0 \mathrm{mmol} \mathrm{L}^{-1}$, Wittwer, 2000). Nevertheless, with the results obtained in this study and information provided by Wittwer (2000), it can be argued that the treatments that included extruded and rolled corn were closer to a condition of ruminal synchrony.

\section{CONCLUSIONS}

The inclusion of extruded corn at levels up to $40 \%$ of the diet of growing steers had no adverse effects on fiber digestibility, contrary to what has been reported in the literature, showing a tendency to higher digestibility of the total ration and of the non-fibrous carbohydrates fraction, composed mainly by starch.

An intake trial conducted with steers showed that increasing extruded corn in the diet did not reduce forage or total intake. In a trial with dairy cows the lower density and greater volume of extruded corn did not reduce intake; this result was obtained when corn grain was included at $20 \%$ of the ration DM, which does not agree with previous research conducted elsewhere with higher levels of extruded corn.

Milk protein and lactose yields were higher with extruded corn than with ground corn, but without clear differences compared to rolled corn. This response is associated with the higher ruminal degradability of extruded corn, which indicates greater delivery of energy in the rumen.

In turn, blood metabolites and milk composition parameters do not suggest a better ruminal synchrony due to the type of processed corn used. 


\section{ACKNOWLEDGEMENTS}

We are grateful to COAGRA S.A. for funding this study (Agreement $\mathrm{N}^{\circ}$ 290704-01/EN between this company and the Universidad Austral de Chile). As well, we thank the personnel of the Animal Nutrition Laboratory and of the Vista Alegre Experimental Station of the Universidad Austral de Chile, for the use of facilities and assistance provided while carrying out the experiments.

\section{RESUMEN}

Efecto de la inclusión de maíz extruido, rolado o molido en dietas de vacas lecheras basadas en ensilaje de pradera de corte directo. Se estudiaron los efectos del procesamiento del grano de maíz (Zea mays L.) en el consumo y digestibilidad de la dieta, y en la composición y producción láctea. En el ensayo 1 se evaluó el efecto de la extrusión en la digestibilidad de la dieta utilizando maíz molido como control. En el ensayo 2 se evaluó el efecto de la extrusión en el consumo comparando maíz extruido de dos densidades (357 y $308 \mathrm{~g} \mathrm{~L}^{-1}$ ) usando maíz rolado (507 $\mathrm{g} \mathrm{L}^{-1}$ ) como control. En el ensayo 3 se evaluó el efecto de la extrusión sobre la producción de leche, digestibilidad y consumo, empleando maíz rolado y maíz molido como controles. No se observaron diferencias en consumo de materia seca (MS) ni de energía metabolizable atribuibles a diferencias de densidad del maíz extruido. La digestibilidad de la MS, materia orgánica, proteína bruta, energía bruta y fibra detergente neutro no difirió entre tratamientos, aunque se observó una mayor digestibilidad de los carbohidratos no fibrosos. Hubo mayor producción de leche en tratamientos donde se incluyó maíz extruido y maíz rolado $\left(21,4\right.$ y $\left.21,6 \mathrm{~L} \mathrm{~d}^{-1}\right)$, respecto del maíz molido $\left(20,5 \mathrm{~L} \mathrm{~d}^{-1}\right)$, pero esta diferencia no se mantuvo al corregir por contenido graso. Los tratamientos no afectaron la composición láctea. La producción diaria de proteína fue mayor $(\mathrm{P}<0,01)$ en los tratamientos con maíz extruido y rolado y no hubo diferencias en la producción diaria de grasa. La urea y ß-hidroxibutirato sanguíneos y urea en leche se mantuvieron dentro de los valores de referencia. Se concluyó que el maíz extruido no tuvo efectos adversos sobre la digestibilidad, ni sobre el consumo de forraje y de alimento total, con una leve ventaja en la producción de proteína láctea al comparar con maíz molido, pero sin diferencias claras al comparar con maíz rolado al vapor.

Palabras clave: maíz extruido, consumo, digestibilidad, producción de leche.

\section{LITERATURE CITED}

Anrique, R., R. Fuchslocher, S. Iraira, y R. Saldaña. 2008. Composición de alimentos para el ganado bovino. 87 p. Consorcio Lechero, Universidad Austral de Chile, Instituto de Investigaciones Agropecuarias, Fundación para la Innovación Agraria, Valdivia, Chile.

AOAC. 2000. Official methods of analysis. $17^{\text {th }} \mathrm{ed}$. Horwitz, W. (ed.) AOAC Int., Gaithersburg, Maryland, USA.

Berndt, S. 2002. Composición nutricional y calidad de ensilajes de la zona sur. 114 p. Tesis Ingeniero Agrónomo. Universidad Austral de Chile, Instituto de Producción Animal, Valdivia, Chile.

Chen, K.H., J.T. Huber, C.B. Theurer, R.S. Swingle, J. Simas, S.C. Chan, et al. 1994. Effects of steam flaking of corn and sorghum grains on performance of lactating cows. J. Anim. Sci. 77:1038-1043.

Crocker, L., E. Depeters, J. Fadel, H. Perez-Monti, J. Taylor, J. Wyckoff, and R. Zinn. 1998. Influence of processed corn grain in diets of dairy cows on digestion of nutrients and milk composition. J. Anim. Sci. 81:2394-2407.

Delahoy, J., L. Muller, F. Bargo, T. Cassidy, and L. Holden. 2003. Supplemental carbohydrate sources for lactating dairy cows on pasture. J. Dairy Sci. 86:906915.

Depeters, E., and J. Cant. 1992. Nutritional factors influencing the nitrogen composition of bovine milk: A review. J. Dairy Sci. 75:2043-2070.

Firkins, J., M. Eastridge, N. St-Pierre, and S. Noftsger. 2001. Effects of grain variability and processing on starch utilization by lactating dairy cattle. J. Anim. Sci. 79 (E. Suppl.):E218-E238.

Gaebe, R., D. Sanson, I. Rush, M. Riley, D. Hixon, and S. Paisley. 1998. Effects of extruded corn or grain sorghum on intake, digestibility, weight gain, and carcasses of finishing steers. J. Anim. Sci. 76:20012007.

Garrido, O., y E. Mann. 1981. Composición química, digestibilidad y valor energético de una pradera de pastoreo a través del año. 63 p. Tesis Ingeniero Agrónomo. Universidad Austral de Chile, Facultad de Ciencias Agrarias, Valdivia, Chile.

Goering, H., and P. Van Soest. 1972. Forage fiber analyses (apparatus, reagents, procedures, and some applications). Agric. Handbook No. 379. Agricultural Research Service (ARS), USDA, Washington DC, USA.

Hoover, W. 1986. Chemical factors involved in ruminal fiber digestion. J. Dairy Sci. 69:2755-2766. 
Hoover, W., and T. Miller-Webster. 1998. Role of sugars and starch in ruminal fermentation. p. 1-16. In Eastridge, M. (ed.) Proceedings Tri-State Dairy Nutrition Conference, Fort Wayne, Indiana. 2122 April. Michigan State University, Ohio State University, Purdue University, Fort Wayne, Indiana, USA.

Joy, M., E. Depeters, J. Fadel, and R. Zinn. 1997. Effects of corn processing on the site and extent of digestion in lactating cows. J. Dairy Sci. 80:2087-2097.

Khalili, H., A. Sairanen, K. Hissa, and P. Huhtanen. 2002. Effects of type and treatment of grain and protein source on dairy cow performance. Anim. Sci. 72:573584.

Miron, J., E. Yosef, D. Ben-Ghedalia, L.E. Chase, D.E. Bauman, and R. Solomon. 2002. Digestibility by dairy cows of monosaccharide constituents in total mixed rations containing citrus pulp. J. Dairy Sci. 85:89-94.

NRC. 2001a. Nutrient requirements for dairy cattle. Chapter 15. Nutrient composition feed. $7^{\text {th }}$ revised ed. p. 281-314. National Research Council (NRC), Washington D.C., USA.

NRC. 2001b. Nutrient requirements for dairy cattle. Chapter 13. Carbohydrate chemistry and feed processing. $7^{\text {th }}$ revised ed. p. 249-257. National Research Council (NRC), Washington D.C., USA.

Oliveira, J.S., J.T. Huber, D. Ben-Ghedalia, R.S. Swingle, C.B. Theurer, and M. Pessarakli. 1993. Influence of sorghum grain on performance of lactating cows. J. Dairy Sci. 76:575-585.

Phillips, C. 2001. Principles of cattle production. 288 p. CABI Publishing, London, England.

Plascencia, A., and R. Zinn. 1996. Influence of flake density on the feeding value of steam-processed corn in diets for lactating cows. J. Anim. Sci. 74:310-316.

Prestløkken, E., and O. Harstad. 2001. Effect of expandertreating a barley-based concentrate on ruminal fermentation, bacterial $\mathrm{N}$ synthesis, escape of dietary $\mathrm{N}$, and performance of dairy cows. Anim. Feed Sci. Technol. 90:227-246.

Rastani, R., and S. Andrew. 1999. The feeding value of extruded corn grain for lactating Holstein dairy cattle. Abstracts Annual Meeting of American Society of Animal Science. J. Anim. Sci. 77S (Suppl. 1):89.
Reis, R., and D. Combs. 2000. Effects of corn processing and supplemental hay on rumen environment and lactation performance of dairy cows grazing grasslegume pasture. J. Dairy Sci. 83:2529-2538.

Rowe, J., M. Choct, and D. Pethick. 1999. Processing cereal grains for animal feeding. Aust. J. Agric. Res. 50:721-736.

Shabi, Z., I. Bruckental, S. Zamwell, H. Tagari, and A. Arieli. 1999. Effects of extrusion of grain and feeding frequency on rumen fermentation, nutrient digestibility, and milk yield and composition in dairy cows. J. Dairy Sci. 82:1252-1260.

Simas, J., J.T. Huber, C.B. Theurer, K.H. Chen, F.A.P. Santos, and Z. Wu. 1997. Influence of fat source and sorghum grain treatment on performance and digestibilities of high yielding dairy cows. J. Dairy Sci. 80:2907-2912.

Steen, R.W.J., F.J. Gordon, L.E.R. Dawson, R.S. Park, C.S. Mayne, R.E. Agnew, et al. 1998. Factors affecting the intake of grass silage by cattle and prediction of silage intake. Anim. Sci. 66:115-127.

Tietz, N.W. 2001. Fundamentals of clinical chemistry. $5^{\text {th }}$ ed. 1091 p. In Burtis, C., and E. Ashwood (eds.) W.B. Saunders, Philadelphia, USA.

Tothi, R., L. Babinszky, and S. Tamminga. 2002. Effect of hydrothermal processing on the feed quality, the ruminal degradation of grains and the milk composition in high producing dairy cows. Krmiva (Zagreb) 44:203-210

Van Soest, P.J., J.B. Robertson, and B.A. Lewis. 1991. Methods for dietary fiber, neutral detergent fiber and non-starch polysaccharides in relation to animal nutrition. J. Dairy Sci. 74:3583-3597.

Wittwer, F. 2000. Diagnóstico dos desequilíbrios metabólicos de energia em rebanhos bovinos. p. 9-22. In F. González et al. (eds.) Perfil metabólico em ruminantes. Seu uso em nutrição e doenças nutricionais. Universidade Federal do Rio Grande do Sul, Porto Alegre, Rio Grande do Sul, Brasil.

Yu, P., J. Huber, F. Santos, J. Simas, and C. Theurer. 1998. Effects of ground, steam-flaked, and steam-rolled corn grains on performance of lactating cows. J. Dairy Sci. 81:777-783. 